\title{
Development of Evaluation Instruments for Learning Midwifery Skills; E-Learning Based Rubric
}

\author{
Ulfa Farrah Lisa ${ }^{1, *}$ Feni Andriani ${ }^{1}$
}

\author{
${ }^{1}$ Faculty of Medicine, Andalas University \\ *Corresponding author. Email: ulfafarrahlisa@med.unand.ac.id
}

\begin{abstract}
Assessment using rubrics can assess students' cognitive, affective, and psychomotor domains when performing midwifery skills. Evaluation instrument analysis software has been developed a lot developed by Andalas University, namely, through web e-learning. The research objective was to produce an evaluation instrument for clinical skills learning. This type of research is research and development or Research and Development (R\&D); the analysis used is the analysis of validity, practicality, and effectiveness. The results of the percentage of product achievement validity from material experts are $100 \%, \mathrm{v}=1.00$, and from media experts, $98.9 \%, \mathrm{v}=0.99$ in the excellent category, the practicality test results from instructors are $96.1 \%$. From students, $91 \%$ with the practical variety, the impact of passing scores between the intervention and control groups was 0,000 . The median in the intervention group was three days, and the control group was nine days. The assessment instrument using a checklist on the e-learning page helps assess midwifery skills' learning outcomes, where the instructor can evaluate and provide feedback on each criterion of skills being tested and reduce the subjective assessment, the scores can be directly downloaded and submitted to the course coordinator.
\end{abstract}

Keywords: Learning evaluation instrument, rubric, eLearning

\section{INTRODUCTION}

Assessment is an essential component of every education. If the lecturer assesses teaching activities, students' learning effectiveness can be increased. Rubrics are performance standards for individual competencies. The assessment rubric provides many benefits to students, lecturers, and agencies. Rubrics provide input and feedback to improve skills and help clarify students' goals and abilities [1].

Digital technology is playing an increasingly important role in all types of assessments. Technology can be used to support teachers in the administration and management of assessment data by: 1) using spreadsheets to record data easily, 2) creating relationships between different types of assessment data, 3) providing a way for lecturers to share assessments, 4) capturing enriched assessment data with the use of digital technology [2].
Evaluation in midwifery skills activities in the Undergraduate Midwifery Study Program, Faculty of Medicine, Andalas University was carried out by observing student skills using an assessment instrument in the form of a rubric with a pass limit of 81. Assessment using a rubric can assess students' cognitive, affective, and psychomotor domains when performing midwifery skills. Evaluation instrument analysis software has been developed a lot by Andalas University, namely elearning. In this study, an electronic-based Block 3A learning evaluation instrument using an e-learning information system will be developed, namely www.ilearn.fk.unand.ac.id.

The interview results with the clinical skills coordinator showed that the manual rubric assessment required time for the addition so that the assessment results were often not given according to the schedule. It was estimated that $20 \%$ of the lecturers gave the score on time. So it is hoped that the development of an elearning-based learning evaluation instrument for 
midwifery skills blocks 3A can help these problems.

The purpose of this study is to produce an elearning- based block 3A clinical skills learning evaluation instrument in the Undergraduate Midwifery Study Program, Faculty of Medicine, Andalas University.

\section{METHODS}

This type of research is Research and Development (R\&D). The procedure in developing the learning evaluation instrument being developed is:

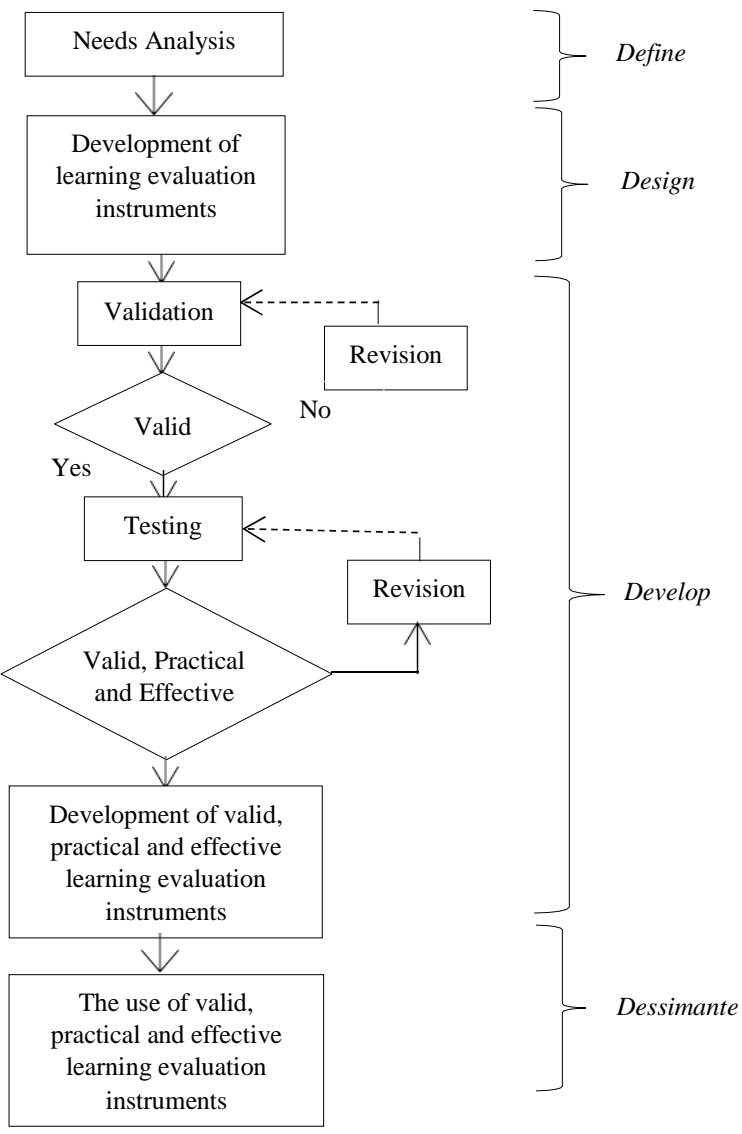

Figure 1 Procedure Chart Development of learning evaluation instruments

Data analysis techniques are:

1. Validity analysis, conducted using the validity coefficient of Aiken's V. Aiken formulates the Aiken's V formula to calculate the Content Validity Coefficient based on the expert's assessment of (n) people on the item regarding the extent to which the thing is able to measure something to be measured. The validity analysis was calculated using the Aiken's V.

2. Practicality analysis, seen from the questionnaire filled out by instructors and students.
3. Effectiveness analysis was conducted to determine the level of effectiveness of the media applied in learning. Significance is determined through the instructor's timeliness of giving test scores to the course coordinator between the intervention group, namely the group using the product, compared to the control group, namely using the manual assessment instrument. The statistical test used is the Mann Whitney test.

\section{RESULTS AND DISCUSSION}

\subsection{Results}

The development of an evaluation instrument for Block 3A midwifery clinical skills learning was carried out from April to May 2020. The development of the tool using the $4 \mathrm{D}$ model and the product that has been carried out at this time is the development stage with the validity test of material experts and media experts and practical difficulties of the instructor side of Midwifery Skills and the student side. The following are the results of the development of the learning evaluation instrument that has been carried out:

\subsubsection{Validity test}

The validity test in this development was validated by material experts, namely the Coordinator of Block 3A Midwifery Skills for the Undergraduate Program in Midwifery, Faculty of Medicine, Andalas University, and media experts from Andalas University.

Table 1 The material expert's answer to the learning evaluation instrument uses the e-learning web

\begin{tabular}{|c|c|c|c|}
\hline No. & $\begin{array}{l}\text { Validation } \\
\text { Aspects }\end{array}$ & Indicator & Score \\
\hline \multirow[t]{8}{*}{1} & \multirow[t]{8}{*}{$\begin{array}{c}\text { Content } \\
\text { (Material) }\end{array}$} & $\begin{array}{l}\text { 1. Conformity of the assessment } \\
\text { criteria with the Midwifery } \\
\text { Skills Guide }\end{array}$ & 5 \\
\hline & & $\begin{array}{l}\text { 2. The conformity of the } \\
\text { assessment criteria with } \\
\text { competence }\end{array}$ & 5 \\
\hline & & $\begin{array}{l}\text { 3. Conformity of the assessment } \\
\text { criteria with the Midwifery } \\
\text { Skills Guide }\end{array}$ & 5 \\
\hline & & $\begin{array}{l}\text { 4. Conformity and clarity of the } \\
\text { assessment criteria }\end{array}$ & 5 \\
\hline & & $\begin{array}{l}\text { 5. Completeness of the assessment } \\
\text { criteria }\end{array}$ & 5 \\
\hline & & $\begin{array}{l}\text { 6. The assessment criteria are easy } \\
\text { to understand }\end{array}$ & 5 \\
\hline & & $\begin{array}{l}\text { 7. Clarity of level/point of } \\
\text { assessment }\end{array}$ & 5 \\
\hline & & $\begin{array}{l}\text { 8. Make it easy to learn } \\
\text { independently }\end{array}$ & 5 \\
\hline 2 & Assessment & 9. Ease of giving an assessment & 5 \\
\hline
\end{tabular}




\begin{tabular}{|c|c|c|c|}
\hline \multirow{2}{*}{} & & $\begin{array}{l}\text { 10. Conformity between learning } \\
\text { outcomes and assessment } \\
\text { criteria }\end{array}$ & 5 \\
\cline { 3 - 4 } & $\begin{array}{l}\text { 11. The level of the evaluation is by } \\
\text { learning outcomes }\end{array}$ & 5 \\
\hline 3 & Feedback & $\begin{array}{l}\text { 12. The feedback column makes it } \\
\text { easy for testers }\end{array}$ & 5 \\
\cline { 2 - 4 } & $\begin{array}{l}\text { 13. The feedback column can } \\
\text { provide input to students to } \\
\text { hone skills }\end{array}$ & 5 \\
\hline Prosentase $=$ & $\frac{\sum \text { answer } \mathrm{x} \text { weight }}{\mathrm{N} x \text { the highest score * }}$ & 100 \\
\hline
\end{tabular}

$*$ the highest score $=5$

Based on the table above, it is found that the material expert which is called Midwifery Skills coordinator, believes that the learning evaluation instrument product developed by the researcher using the e-learning web media can be used to help the Midwifery Skills test process, which is very feasible to apply with the result that the percentage of product achievement is $100 \% . \mathrm{v}=1.00$, which is a valid assessment instrument.

Table 2 The media expert's answer to the learning evaluation instrument using the e-learning web

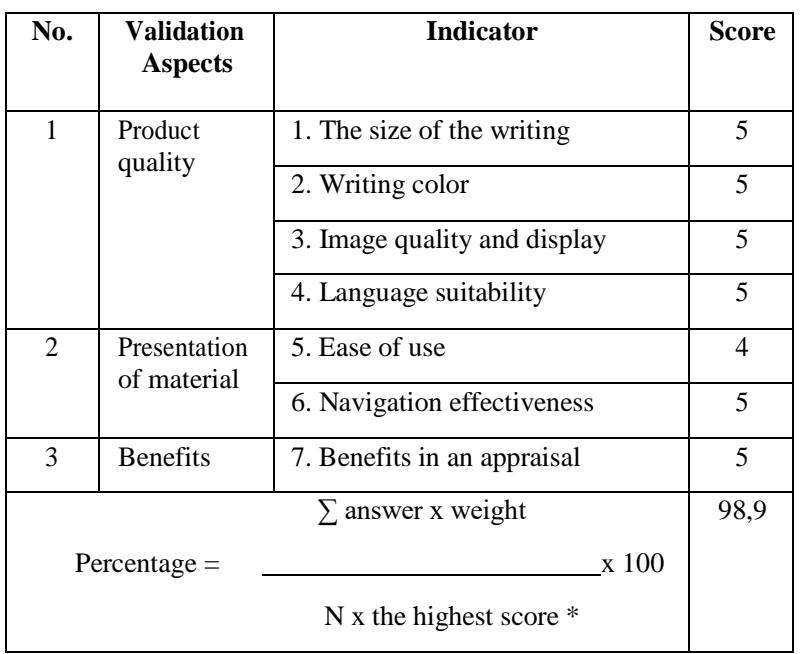

$*$ the highest score $=5$

Based on the table above, it is found that media experts argue that the learning evaluation instrument using e- learning media developed by this researcher can be used to help the student skills test process with a product achievement level of $98.9 \%$ with $\mathrm{v}=0.99$, which is a valid assessment instrument.

\subsubsection{Practicality Test}

The practicality test in this development was assessed by 2 Midwifery Skills instructors and ten representatives from the midwifery study program students.

Table 3 Results of the practicality assessment of the Midwifery Skills Instructor

\begin{tabular}{|c|c|c|c|c|}
\hline \multirow[t]{2}{*}{ No. } & \multirow{2}{*}{$\begin{array}{l}\text { Validati } \\
\text { on } \\
\text { Aspects }\end{array}$} & \multirow[t]{2}{*}{ Indicator } & \multicolumn{2}{|c|}{ Score } \\
\hline & & & Inst1 & Inst2 \\
\hline \multirow[t]{4}{*}{1} & \multirow{4}{*}{$\begin{array}{l}\text { Product } \\
\text { quality }\end{array}$} & 1. Access the e-learning web & 5 & 5 \\
\hline & & 2. Media Display & 5 & 5 \\
\hline & & $\begin{array}{l}\text { 3. Accuracy of content and } \\
\text { attractiveness of contents }\end{array}$ & 4 & 5 \\
\hline & & 4. Use of media & 5 & 5 \\
\hline \multirow[t]{7}{*}{2} & \multirow{7}{*}{$\begin{array}{l}\text { Presentati } \\
\text { on of } \\
\text { material }\end{array}$} & $\begin{array}{l}\text { 5. Accuracy of material and } \\
\text { accuracy of language }\end{array}$ & 4 & 5 \\
\hline & & $\begin{array}{l}\text { 6. Conformity and clarity of } \\
\text { the assessment criteria }\end{array}$ & 4 & 4 \\
\hline & & $\begin{array}{r}\text { 7. Completeness of the } \\
\text { assessment criteria }\end{array}$ & 5 & 5 \\
\hline & & $\begin{array}{l}\text { 8. The assessment criteria are } \\
\text { easy to understand }\end{array}$ & 4 & 5 \\
\hline & & $\begin{array}{l}\text { 9. Clarity of level/point of } \\
\text { assessment }\end{array}$ & 4 & 5 \\
\hline & & $\begin{array}{l}\text { 10. Feedback can make it } \\
\text { easier for students to study } \\
\text { independently }\end{array}$ & 5 & 5 \\
\hline & & $\begin{array}{l}\text { 11. Completeness of } \\
\text { instructions }\end{array}$ & 5 & 5 \\
\hline \multirow[t]{7}{*}{3} & \multirow[t]{7}{*}{ Benefits } & 12. Ease of use & 4 & 5 \\
\hline & & 13. Ease of the exam process & 5 & 5 \\
\hline & & 14. Scheduled exam process & 5 & 5 \\
\hline & & $\begin{array}{l}\text { 15. Ease of providing } \\
\text { feedback }\end{array}$ & 5 & 5 \\
\hline & & $\begin{array}{l}\text { 16. The value that can be seen } \\
\text { after the test }\end{array}$ & 5 & 5 \\
\hline & & 17. Ease of capturing value & 5 & 5 \\
\hline & & $\begin{array}{l}\text { 18. Time efficiency in grading } \\
\text { the Midwifery Skills } \\
\text { Coordinator }\end{array}$ & 5 & 5 \\
\hline \multicolumn{3}{|r|}{$\sum$ answer $\mathrm{x}$ weight } & 93,3 & 98,9 \\
\hline \multirow{2}{*}{\multicolumn{2}{|c|}{ Percentage $=$}} & $\mathrm{N} x$ the highest score $*$ & & \\
\hline & & Average & & \\
\hline
\end{tabular}

$*$ the highest score $=5$

Based on the table above, it is found that the Midwifery Skills Instructor believes that the product of the Midwifery Skills learning evaluation instrument using the e-learning web can help the assessment of skills exams more easily and can provide feedback that can be seen directly by students, which hopefully will be an improvement for students in the future.

Midwifery Skills Instructors are also very helpful in adding and collating grades so that they are efficient in the time of submitting scores to the Midwifery Skills Coordinator. The achievement level of the practicalized test by the Midwifery Skills instructor was $96.1 \%$ in the very practical category 
Table 4 The results of the practicality assessment of students

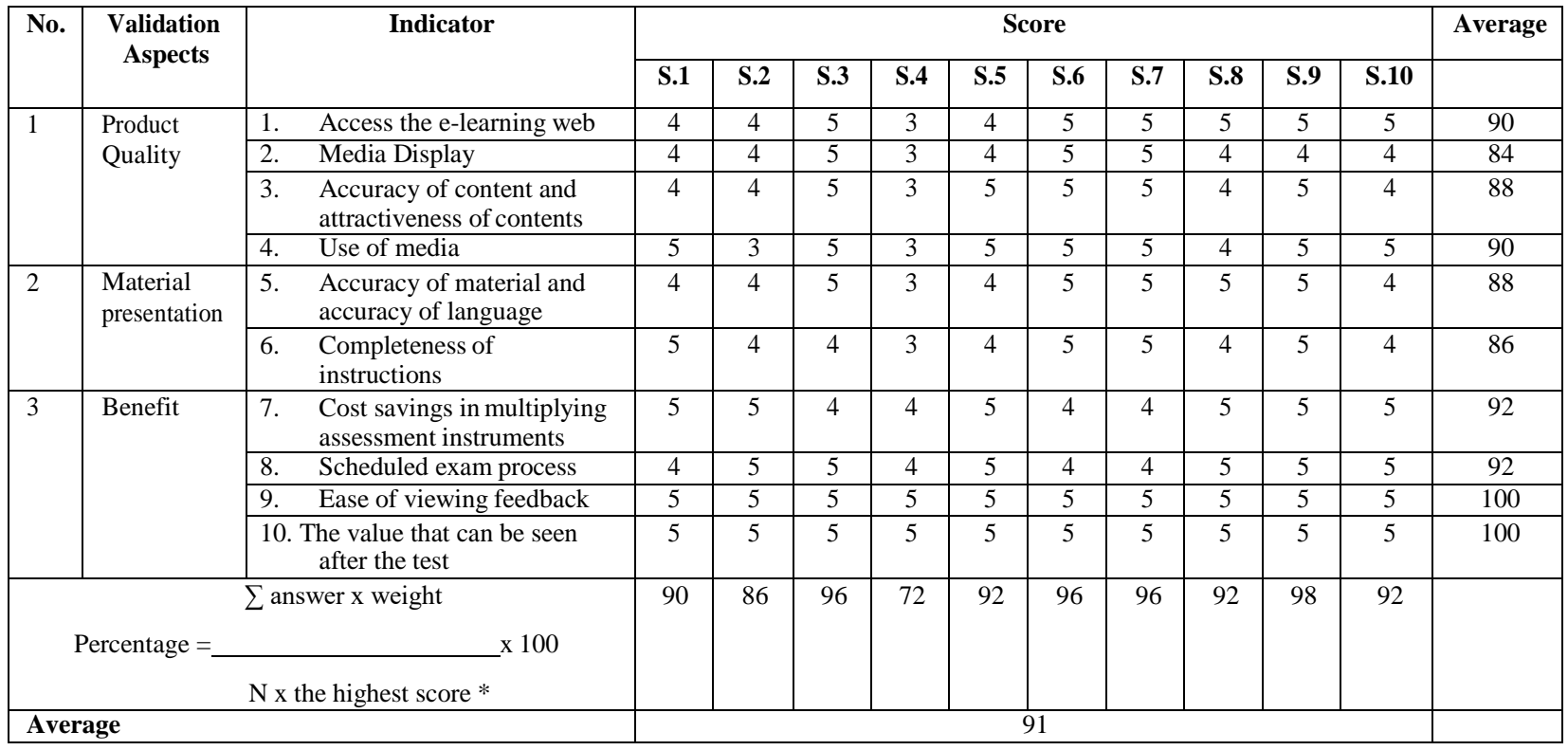

$*$ the highest score $=5$

Based on the table above, it was found that $100 \%$ students were interested in the feedback column on the KK learning evaluation instrument on the e-learning website, where students could find out what skills were lacking and which parts had to be improved. Students also think that the value that can be seen after the test is an important thing, where the achievement score is $100 \%$. The students will know immediately whether they passed the test on that skill or not. By displaying the scores after the trial, students with low scores can prepare themselves for the next skills test to make up the low scores on the previous exam. Overall, student opinion on the learning evaluation instrument is very practical, with $91 \%$ achievement.

\subsubsection{Effectiveness Test}

This study compared the clinical skills exam midwifery scores using manual assessment rubrics (control group) and the group using assessment rubric through web e- learning. Research data that have been obtained from this research can be seen in the following table:

Table 5 The effectiveness of using the learning evaluation instrument using an e-learning-based rubric

\begin{tabular}{lccc}
\hline $\begin{array}{c}\text { Time of } \\
\text { Submission of } \\
\text { Value }\end{array}$ & $\begin{array}{c}\text { Intervention } \\
\text { Group }\end{array}$ & $\begin{array}{c}\text { Control } \\
\text { Group }\end{array}$ & $p$ value \\
\hline Mean & 3,94 & 9,24 & \\
SD & 1,03 & 2,11 & 0,000 \\
Median & 3 & 9 & \\
Range & $3-5$ & $7-12$ & \\
\hline
\end{tabular}

The results of the calculation showed that the time of submission scores in the intervention group, namely the group using the assessment instrument on the elearning page, had a smaller median of 3 days compared to the median in the control group, which need nine days, with a range of 3-5 days for the intervention group and a range of groups. Control was 7-12 days. The results of statistical tests using the Mann Whitney test showed a significant difference in the time of submission of values between the intervention and control groups, with a p- value of 0.000 .

\subsection{Discussion}

The product development of an e-learning-based learning evaluation instrument for midwifery skills is used by Midwifery Skills instructors as an assessment rubric during exams, which can be accessed on the Faculty of Medicine e-learning web, namely ilearn.fk.unand.ac.id.

The validation results by material and media experts showed that this instrument is suitable to be used in the midwifery skills examination process, and based on the practicality test by Midwifery Skills, instructors and students also get very practical results used in the Midwifery Skills exam process.

Assessment is an essential component of every education. If the lecturer makes an assessment in teaching activities, students' learning effectiveness can be increased. Rubrics are performance standards for specific competencies. The assessment rubric provides some benefits to students, lecturers, and agencies. Rubrics provide input and feedback to help improve skills and are a powerful way to clarify the goals and skills of students [1]. 
Digital technology plays an important role in all types of assessments. Technology can be used to support teachers in the administration and management of assessment data by: 1) using spreadsheets to record data easily, 2) creating relationships between different types of assessment data,

3) providing a way for lecturers to share assessments, 4) capturing enriched assessment data with the use of digital technology [2]

Evaluation instrument analysis software has been developed a lot, one of it is developed at Andalas University through web e-learning. The Online Learning Evaluation Application is a website-based application that easily carries out the learning evaluation process. The learning evaluation in question is a process to determine students' learning value through assessment and measurement of learning outcomes [3]. In this study, the application developed was devoted to evaluating learning using a rubric (assessment rubric) of midwifery skills.

A rubric can also be a student learning aid to apply the literature evaluation concept to the study being tested. Rubrics can be a useful tool for evaluating student learning outcomes by displaying skills according to learning outcomes. The rubric that has been filled/assessed by the lecturer will be a good learning aid for students to use in evaluating their skills; therefore, after the assessment, the rubric must be distributed to students to identify deficiencies of the skills that have been tested. This feedback will help learners to improve in the future (Matthew L, 2007).

Reynders, Gil et al. (2020) concluded the results of their research that the use of rubrics can be used to provide feedback on aspects of individual student skills, instructors can achieve constructive alignment between the desired results and their assessments, and by using rubrics can improve alignment to improve each student's skills and assessed objectively.

Beatrice A (2009) also argued in her research that in medical education, rubrics offer additional benefits, namely: 1) Determining indicators and learning outcomes, 2) Ensuring a coherent and consistent assessment for all students, 3) Measuring student learning outcomes based on criteria direct skills, 4) Provide opportunities for students to demonstrate their skills in competency and clinical learning evaluation, 5) Improve the quality of assessment and reduce subjective assessments.

The rubric provides an understanding of the relationship between learning outcomes and outcomes. Alignment of results and assessments is the basis for drawing valid conclusions about learning. It is hoped that at the end of the student practice cycle in the field, the evaluations and feedback received during the process will produce doctors who are more competent and better at practicing independently.
The results of research by Urios et al. (2015), found that it is necessary to develop an assessment rubric to see the skills of students according to the needs, that the rubric is useful as an assessment tool, but to increase Utility as a tool in the learning process, the future challenge is modifying some aspects of the process validator and question.

In this study, before the learning evaluation instrument was inserted into the e-learning web, the research team first reviewed each assessment criterion and assessment points. Each assessment point is given an explanation according to the student's appearance during the exam. The assessment criterias are also adjusted to the learning outcomes and Midwifery Skills guidelines. From the validation results from material experts, all requirements can be understood and are in accordance with learning outcomes and procedures. Material experts argue that this instrument is very feasible to be applied to the examination process.

The e-learning-based learning evaluation instrument includes instructions on filling in the tool on the Web page of the Subjects to be tested (Figure 2). Students after the exam (Figure 3). The score can be seen directly by the Midwifery Skills instructor after the exam is over so that the Midwifery Skills instructor can see who had take the Midwifery Skills exam. The scores can be downloaded in the form of excel, this dramatically saves time in compiling and submitting scores to the Midwifery Skills coordinator (figures 4 and 5). Students also greatly benefit from the practicality of the elearning-based learning evaluation instrument. Students can see the assessment rubric that will be assessed during the skills test, and the students can see the value and feedback from the lecturer after the exam is completed. The shortcomings of these midwifery skills are help students who get low scores, to have better preparation for the next exam to cover the lower of scores from the previous exam (figure 6)

\section{CONCLUSION}

The evaluation instrument for Midwifery Skills learning developed using electronic media, namely the Medical Faculty web e-learning, is very useful for students, Midwifery Skills Instructors, Midwifery Skills Coordinators, and Institutions so that the results of this development can be applied to other courses to evaluate the skills of students.

\section{ACKNOWLEDGMENT}

This research goes well with the support of funding from LPPPM Andalas University. On this occasion, the authors would like to thank the LPPPM for funding this research, so that this research produces results that can be published in ICED QA III and the results can also be applied in the learning process in 
the midwifery study program of the Medical Faculty of Andalas University.

\section{REFERENCES}

[1]Surwano. Pentingnya Rubrik Penilaian Dalam Penilaian Keterampilan Vocational Siswa. Prosiding Seminar Nasional UNS Vocational Day, 2016, 25416731 (Online).

[2] Winaryati, Eny, Penilaian Kompetensi Siswa Abad 21. Seminar Nasional Edusainstek FMIPA UNIMUS, 2018, ISBN : 978-602-5614-35-4.

[3]Fuady, Muhammad Jauharul, Pengembangan Aplikasi Evaluasi Pembelajaran Online Untuk Pendidikan Jarak Jauh. TEKNO, Vol 26 September 2016, ISSN : 1693-8739.

[4] Matthew L, et al, Instructional Design And Assessment; A Rubric to Assess Critical Literature Evaluation Skills. American Journal of Pharmaceutical Education 2007; 71 (4) Article 63.

[5] Reynders, Gil, et al. Rubrics to assess critical thinking and information processing in undergraduate STEM courses. International Journal of STEM Education, 2020, https://doi.org/10.1186/s40594-020-00208-5

[6]Beatrice A, et al, The Development of a Competency- Based Assessment Rubric to Measure Resident Milestones. Journal of Graduate Medical Education, September 2009

[7]Urios, Montserrat Iborra et al, Generic skill development and learning/assessment process: Use of rubrics and student validation. Journal of Technology and Science Education. Vol 5(2), 2015, pp 107 On-line ISSN 2013-6374 - Print-ISSN 2014-
5349
DL:
B-2000-2012

-http://dx.doi.org/10.3926/jotse.147 
Figure 2 Instructions for the use of the assessment instrument

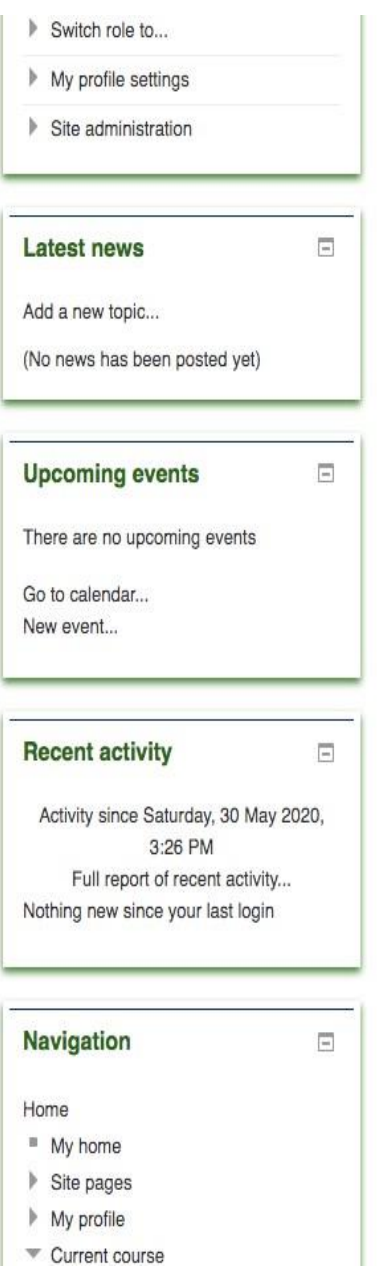

\section{Ujian Pemeriksaan Kehamilan (ANC)}

Penilaian Pemeriksaan Kehamilan

Ujian ini bertujuan untuk melihat keterampilan mahasiswa dalam melakukan anamnesis dan pemeriksaan fisik pada ibu hamil.

Petunjuk untuk Instruktur KK:

Berilah nilai sesuai point yang tertera pada rubrik penilaian dengan cara mengklik pada kolum point penilaian sesuai dengan penampilan mahasiswa dalam melakukan keterampilan pemeriksaan kehamilan.

\section{Ujian Keterampilan KIE Skrining HIV}

Penilaian Keterampilan KIE

Ujian ini bertujuan untuk melihat keterampilan mahasiswa dalam melakukan KIE dalam skrining HIV.

Petunjuk untuk Instruktur KK:

Berilah nilai sesuai point yang tertera pada rubrik penilaian dengan cara mengklik pada kolum point penilaian sesuai dengan penampilan mahasiswa dalam melakukan KIE

\section{Ujian Keterampilan Senam Hamil}

Penilaian Keterampilan Senam Hami

Ujian ini bertujuan untuk melihat keterampilan mahasiswa dalam melakukan senam hamil.

Petunjuk untuk Instruktur KK: 
Figure 3 The feedback column

\section{Feedback}

\begin{tabular}{|c|c|c|c|c|c|}
\hline \multirow[t]{7}{*}{ Grade } & \multicolumn{5}{|c|}{$\begin{array}{l}\text { Ujian ini bertujuan untuk melihat keterampilan mahasiswa dalam melakukan anamnesis dan pemeriksaan fisik pad } \\
\text { hamil. }\end{array}$} \\
\hline & \multicolumn{5}{|l|}{ Petunjuk: } \\
\hline & \multicolumn{5}{|c|}{$\begin{array}{l}\text { Berilah nilai sesuai point yang tertera pada rubrik penilaian dengan cara mengklik pada kolum point penilaian sesu } \\
\text { dengan penampilan mahasiswa dalam melakukan keterampilan pemeriksaan kehamilan. }\end{array}$} \\
\hline & $\begin{array}{l}\text { Menyambut ibu dan } \\
\text { pendamping ibu }\end{array}$ & $\begin{array}{l}\text { Perlu Perbaikan } \\
\text { (Langkah / tugas } \\
\text { tidak dikerjakan) } \\
\text { o points }\end{array}$ & \begin{tabular}{|l} 
Mampu \\
(Langkah / tugas \\
dikerjakan tetapi \\
kurang tepat) \\
1 points
\end{tabular} & $\begin{array}{l}\text { Mahir (Langkah } \\
\text { dikerajakan } \\
\text { dengan benar, } \\
\text { tepat, dan tanpa } \\
\text { ragu - ragu } \\
\text { sesuai prosedur) } \\
2 \text { points }\end{array}$ & kurang komunikatif \\
\hline & $\begin{array}{l}\text { Memperkenalkan diri } \\
\text { kepada ibu }\end{array}$ & $\begin{array}{l}\text { Perlu Perbaikan } \\
\text { (Langkah / tugas } \\
\text { tidak dikerjakan) } \\
0 \text { points }\end{array}$ & $\begin{array}{l}\text { Dilakukan } \\
\text { namun tidak } \\
\text { komunikatif } \\
1 \text { points }\end{array}$ & $\begin{array}{l}\text { Mahir (Langkah } \\
\text { dikerajakan } \\
\text { dengan benar, } \\
\text { tepat, dan tanpa } \\
\text { ragu - ragu } \\
\text { sesuai prosedur) } \\
2 \text { points }\end{array}$ & \\
\hline & $\begin{array}{l}\text { Menjelaskan prosedur } \\
\text { yang akan dilakukan }\end{array}$ & $\begin{array}{l}\text { Perlu Perbaikan } \\
\text { (Langkah / tugas } \\
\text { tidak dikerjakan) } \\
\text { o points }\end{array}$ & \begin{tabular}{|l} 
Dilakukan \\
namun tidak \\
komunikatif \\
1 points
\end{tabular} & $\begin{array}{l}\text { Mahir (Langkah } \\
\text { dikerajakan } \\
\text { dengan benar, } \\
\text { tepat, dan tanpa } \\
\text { ragu - ragu } \\
\text { sesuai prosedur) } \\
2 \text { points }\end{array}$ & $\begin{array}{l}\text { rasa empati tidak } \\
\text { dimunculkan }\end{array}$ \\
\hline & $\begin{array}{l}\text { Meminta persetujuan } \\
\text { pasien terhadap } \\
\text { tindakan vana akan }\end{array}$ & $\begin{array}{l}\text { Perlu Perbaikan } \\
\text { (Langkah / tugas } \\
\text { tidak dikeriakan) }\end{array}$ & $\begin{array}{l}\text { Dilakukan } \\
\text { namun tidak } \\
\text { komunikatif }\end{array}$ & $\begin{array}{l}\text { Mahir (Langkah } \\
\text { dikerajakan } \\
\text { dencan benar. }\end{array}$ & tidak komunikatif \\
\hline
\end{tabular}

Figure 4 student scores after the exam

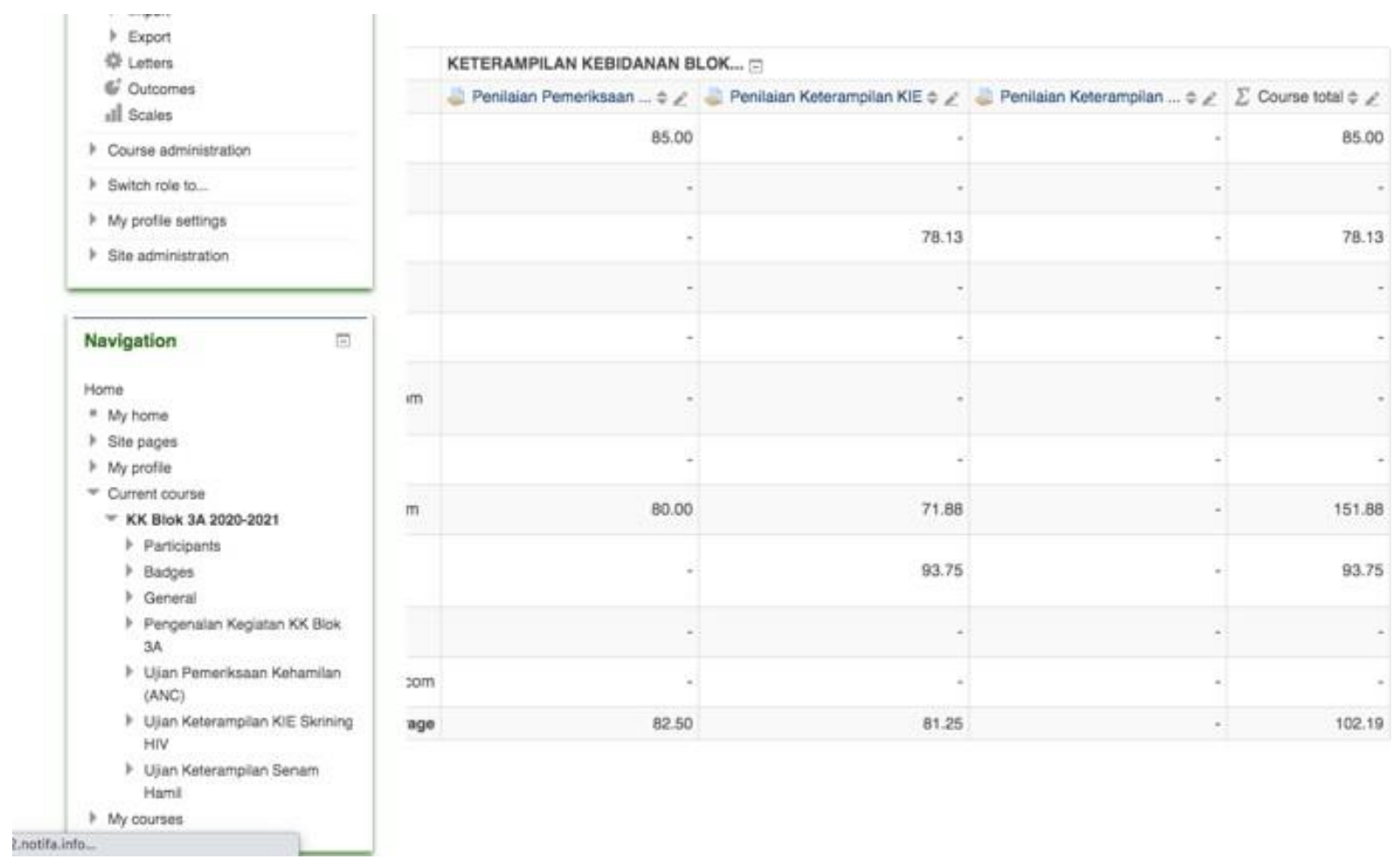


Figure 5 Download results of student scores in excel

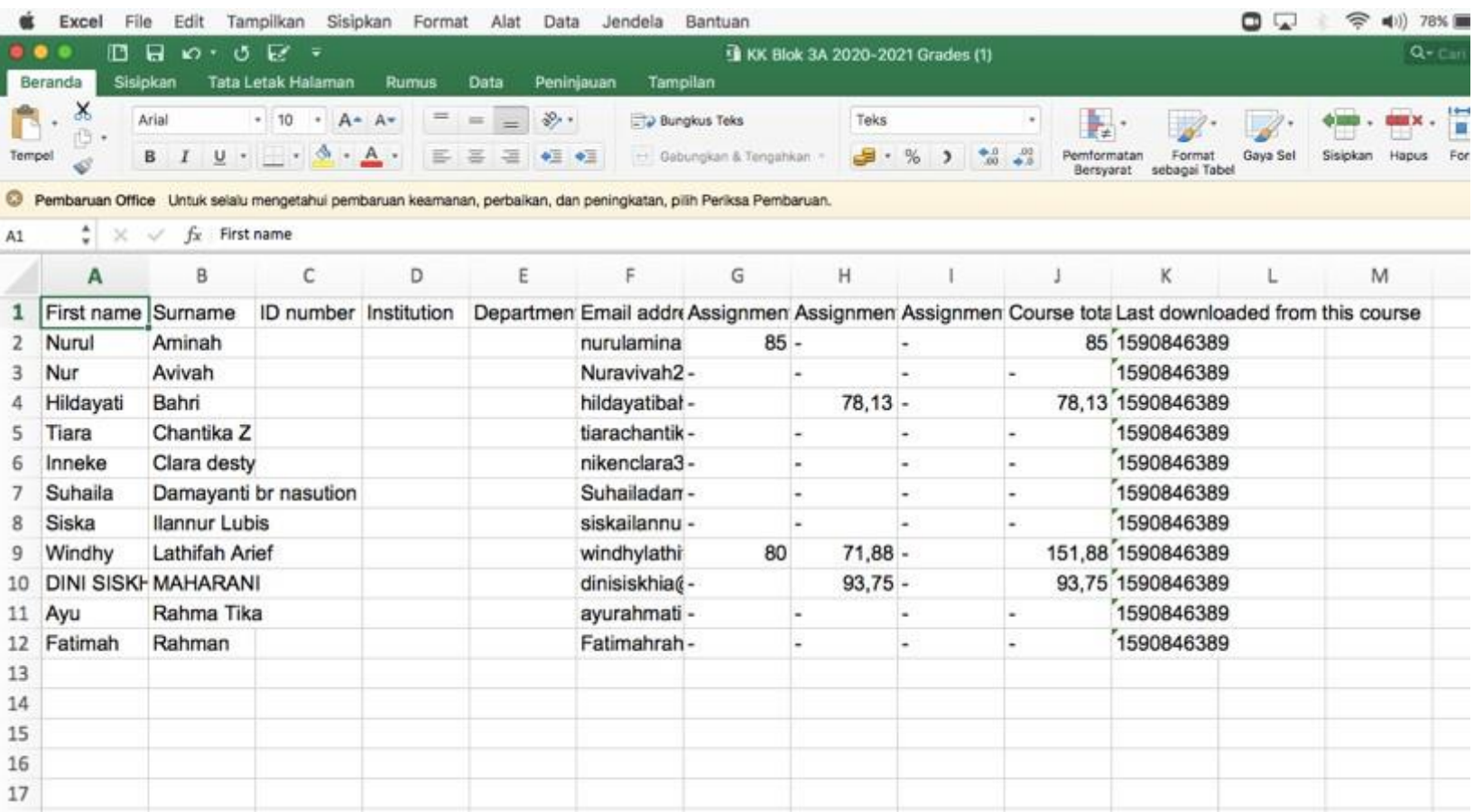

Figure 6 The score on the e-learning web page that is visible to students

\begin{tabular}{|c|c|c|c|c|c|c|}
\hline to students & - $\quad--$ & & & - & - & - \\
\hline & $\begin{array}{l}\text { Memberikan KIE sesuai } \\
\text { kebutuhan }\end{array}$ & $\begin{array}{l}\text { Langkah / tugas } \\
\text { tidak dikerjakan } \\
0 \text { points }\end{array}$ & $\begin{array}{l}\text { Langkah } \\
\text { dilakukan tidak } \\
\text { lengkap dan } \\
\text { tidak komunikatif } \\
1 \text { points }\end{array}$ & \begin{tabular}{|l|} 
Langkah \\
dikerajakan \\
dengan benar, \\
tepat, dan tanpa \\
ragu - ragu \\
sesuai prosedur \\
2 points
\end{tabular} & & \\
\hline & Dokumentasi SOAP & $\begin{array}{l}\text { Langkah / tugas } \\
\text { tidak dikerjakan } \\
0 \text { points }\end{array}$ & $\begin{array}{l}\text { Langkah } \\
\text { dilakukan tidak } \\
\text { lengkap dan } \\
\text { tidak komunikatif } \\
1 \text { points }\end{array}$ & \begin{tabular}{|l|} 
Langkah \\
dikerajakan \\
dengan benar, \\
tepat, dan tanpa \\
ragu - ragu \\
sesuai prosedur \\
2 points \\
\end{tabular} & & \\
\hline & $\begin{array}{l}\text { Menjadwalkan } \\
\text { kunjungan berikutnya } \\
\text { (kunjungan ulang) }\end{array}$ & $\begin{array}{l}\text { Langkah / tugas } \\
\text { tidak dikerjakan } \\
0 \text { points }\end{array}$ & $\begin{array}{l}\text { Langkah } \\
\text { dilakukan tidak } \\
\text { lengkap dan } \\
\text { tidak komunikatif } \\
1 \text { points }\end{array}$ & $\begin{array}{l}\text { Langkah } \\
\text { dikerajakan } \\
\text { dengan benar, } \\
\text { tepat, dan tanpa } \\
\text { ragu - ragu } \\
\text { sesuai prosedur } \\
2 \text { points } \\
\end{array}$ & & \\
\hline & \multicolumn{6}{|l|}{$85.00 / 100.00$} \\
\hline Graded on & \multicolumn{6}{|c|}{ Saturday, 30 May 2020, 8:43 PM } \\
\hline Graded by & \multicolumn{5}{|l|}{ Ulfa Farrah } & \\
\hline $\begin{array}{l}\text { Feedback } \\
\text { comments }\end{array}$ & \multicolumn{6}{|c|}{ Mahasiswa sudah mahir namun kurang komunikatif, perlu dilatih cara komunikasi yang baik. } \\
\hline
\end{tabular}

